\title{
PENGARUH PENERAPAN MODEL PEMBELAJARAN KOOPERATIF TIPE COURSE REVIEW HORAY (CRH) TERHADAP KEAKTIFAN BELAJAR DAN HASIL BELAJAR EKONOMI
}

\author{
(Studi Pada Siswa Kelas XI MIPA SMA Negeri 3 Purwokerto)
}

\author{
Aisyah \\ Fakultas Ekonomi dan Bisnis, Universitas Jenderal Soedirman, Indonesia \\ Email corresponding author : icaaisyah2110@gnmail.com
}

\begin{abstract}
Abstrak
Penelitian ini adalah penelitian eksperimen pada siswa kelas XI MIPA di SMA Negeri 3 Purwokerto. Penelitian ini mengambil judul "Pengaruh Penerapan Model Pembelajaran Kooperatif Tipe Course Review Horay (CRH) terhadap Keaktifan Belajar dan Hasil Belajar Ekonomi (Studi pada Siswa Kelas XI MIPA di SMA Negeri 3 Purwokerto)". Tujuan dari penelitian ini adalah untuk mengetahui perbedaan keaktifan belajar dan hasil belajar antara model pembelajaran Course Review Horay (CRH) dengan model pembelajaran konvensional,untuk mengetahui pengaruh model pembelajaran Course Review Horay (CRH) terhadap keaktifan belajar dan hasil belajar, serta untuk mengetahui pengaruh keaktifan belajar terhadap hasil belajar. Populasi penelitian ini adalah siswa kelas XI MIPA di SMA Negeri 3 Purwokerto. Jumlah sample yang diambil dalam penelitian ini adalah 72 yaitu 2 kelas XI MIPA yang masing-masing kelas berjumlah 36 siswa. Purposive Sampling Method digunakan dalam penentuan sample.

Berdasarkan hasil penelitian dan anallisis data menunjukkan bahwa (1) Terdapat perbedaan signifikan keaktifan belajar antara model pembelajaran kooperatif Course Review Horay (CRH) dengan model pembelajaran konvensional pada mata pelajaran ekonomi. (2) Terdapat perbedaan signifikan hasil belajar antara model pembelajaran kooperatif Course Review Horay (CRH) dengan model pembelajaran konvensional pada mata pelajaran ekonomi. (3) Terdapat pengaruh positif model pembelajaran kooperatifCourse Review Horay (CRH) terhadap keaktifan belajar pada mata pelajaran ekonomi. (4) Terdapat pengaruh positif model pembelajaran kooperatif Course Review Horay (CRH) terhadap hasil belajar pada mata pelajaran ekonomi. (5) Tidak terdapat pengaruh positif antara keaktifan belajar siswa terhadap hasil belajar pada mata pelajaran ekonomi.
\end{abstract}

Kata Kunci : Model Pembelajaran, Course Review Horay (CRH).

\begin{abstract}
This research is experimental research on students class XI of MIPA in SMA Negeri 3 Purwokerto. This research takes the title of "The Influence of the Application of the Cooperative Learning Model Type Course Review Horay (CRH) Against the Liveliness of learning and the Results of the Economic Study (study on the Grade XI MIPA in SMA Negeri 3 Purwokerto)". The purpose of this research is to know the difference in learning outcomes and learning activity between the learning model Course Review Horay (CRH) with conventional learning model, to know the influence of learning model Course Review Horay (CRH) against the learning outcomes and learning activity, as well as to know the influence of the liveliness of the learning results of learning. The population of this research is the grade XI MIPA in SMA Negeri 3 Purwokerto. The number of samples taken in this study is 72 i.e. 2 Class XI of MIPA which each class amounted to 36 students. Purposive Sampling Method used in the determination of the sample.

Based on the results of the research and the anallisis data indicate that (1) there is a significant difference between the model of learning learning activeness cooperative Course Review Horay (CRH) and conventional learning model on economics. (2) there are significant differences between the learning outcomes learning model cooperative Course Review Horay (CRH) and conventional learning model on economi. (3) there is a positive influence learning model cooperativeCourse Review Horay (CRH) against the liveliness of the study on economic. (4) there is a positive influence learning model cooperativeCourse Review Horay (CRH) against the results of the study on economic. (5) there is no positive influence between the liveliness of student learning against the results of the study on economic.
\end{abstract}

Keywords: Learning Model, Course Review Horay (CRH). 


\section{PENDAHULUAN}

Kesesuaian model pembelajaran yang digunakan guru ialah salah satu faktor yang mempengaruhi tingkat keberhasilan siswa dalam proses pendidikan. Model pembelajaran merupakan suatu rencana yang dipersiapkan guru sebelum proses pembelajaran agar tujuan pembelajaran tercapai (Rusman, 2013:133).

Pada proses pembelajaran di kelas, masih banyak guru menerapkan teacher centered atau pembelajaran yang berpusat pada guru. Kondisi tersebut akan membuat siswa memiliki peran sebagai pengikut dan penerima yang cenderung tidak aktif pada proses pembelajaran. Salah satu model pembelajaran yang membuat siswa ikut berperan aktif adalah model pembelajaran kooperatif. Model pembelajaran kooperatif ialah proses penyampaian ilmu pengetahuan kepada siswa yang dilakukan secara berkelompok, tiap kelompoknya terdiri 4-5 siswa yang memiliki kemampuan beragam untuk bekerjasama saling membantu mengkonstruksikan konsep, menyelesaikan persoalan, dan meminta hasil setiap kelompok dalam bentuk laporan atau presentasi (Suyatno, 2009:51).

Pada pembelajaran kooperatif terdapat beragam jenis model yang mampu diimplementasikan oleh guru, salah satu jenispembelajaran kooperatif yaitu Course Review Horay (CRH). Model pembelajaran Course Review Horay (CRH) adalah model pembelajaran yang strukturnya menarik dan tidak membosankan karena diselingi hiburan yang menarik sehingga suasana tidak menegangkan dan mampu mendorong siswa aktif untuk terjun ke dalamnya, semangat belajar siswa akan meningkat karena aktivitas pembelajaran berlangsung menyenangkan (Huda, 2013:236). Cara untuk mengetahui hasil pembelajaran tercapai atau tidak dapat diketahui dengan penilaian.

Penilaian merupakan proses evaluasi dengan tujuan mengetahui seberapa besarcapaian dibandingkan dengan target yang ditetapkan di awal. Penilaian pada proses pembelajaran memiliki fungsi sebagai indicator kesuksesan proses Pendidikan. Pada prinsipnya anak-anak adalah makhluk yang aktif (Aunurrahman, 2013:119). Keaktifan yang dimiliki anak mampu berkembang ke arah yang positif bilamana lingkungannya memberikan ruang yang baik untuk tumbuh suburnya keaktifan itu. Keadaan ini menyebabkan setiap guru perlu menggali potensipotensi yang dimiliki siswa melalui keaktifan, dengan penggunaan model pembelajaran yang sesuai.

SMA Negeri 3 Purwokerto merupakan salah satu lembaga pendidikan tingkat SMA di Banyumas. Pada tahun 2013, sekolah ini menggunakan kurikulum 2013 yang sebelumnya menggunakan KTSP. Pada kurikulum 2013 ini diperlukan kreativitas dan inovasi yang berasal melalui lembaga pendidikan yang melakukan proses pendidikan khususnya pembelajaran. 
Mengacu pada pengamatan yang dilakukan pada kelas XI MIPA di SMA Negeri 3 Purwokerto, bahwa pada proses pembelajaran ekonomi guru belum banyak menggunakan variasi model pembelajaran, sehingga siswa mudah bosan selama kegiatan pembelajaran berlangsung. Guru masih menggunakan pembelajaran konvensional. Pada pembelajaran modelkonvensional, guru sering membiarkan adanya siswa yang menggantungkan diri pada kelompok, kelompok belajar biasanya homogen dan penekanan sering hanya pada penyelesaian tugas (Triatno, 2009:110). Kurangnya keikutsertaan dan keaktifan siswa pada proses pembelajaran akan memiliki pengaruh terhadap hasil belajar siswa. Menurut penelitian yang dilakukan oleh Arti et al., (2016) menunjukan bahwa model pembelajaran kooperatif tipe CRH memberikan pengaruh dan dampak positif pada keaktifan belajar dan hasil belajar matematika siswa kelas VII SMP Kristen 2 Salatiga.

Permasalahan tersebut menyebabkan siswa kurang berhasil secara maksimal dalam pembelajaran ekonomi. Diketahui dari nilai ulangan akhir semester genap pada mata pelajaran ekonomi XI MIPA di SMA Negeri 3 Purwokerto yang menunjukan masih banyak nilai siswa yang kurang dari Kriteria Ketuntasan Minimal (KKM). KKM yang ditentukan oleh sekolah yaitu nilai 66. Berikut data ketercapaian KKMsiswa kelas XI MIPA di SMA Negeri 3 Purwokerto:

Tabel1. Nilai Akhir Semester Genap Pelajaran Ekonomi Tahun Pelajaran 2018/2019

\begin{tabular}{cccccc}
\hline \multirow{2}{*}{ No } & \multirow{2}{*}{ Kelas } & Jumlah Siswa & \multicolumn{2}{c}{ Interval Nilai } & Nilai \\
& & $\mathbf{6 6 6}$ & $\mathbf{> 6 6}$ & Rata-rata \\
\hline 1. & XIMIPA 1 & 35 & 20 & 15 & 56,1 \\
2. & XI MIPA 2 & 35 & 29 & 6 & 52.9 \\
3. & XI MIPA 3 & 36 & 25 & 11 & 52,8 \\
\hline & & 106 & 74 & 32 & 53,9 \\
\hline
\end{tabular}

Sumber: Dokumentasi nilai sumatif guru mapel ekonomi SMA N 3 Purwokerto

Mengacu pada penjelasan di atas peneliti tertarik untuk melakukan penelitian dengan topik pengaruh penerapan model pembelajaran kooperatif tipe CRH terhadap keaktifan belajar dan hasil belajar ekonomi (studi pada siswa kelas XI MIPA di SMA Negeri 3 Purwokerto).

\section{Tujuan Penelitian}

Menganalisis perbedaan keaktifan belajar siswa antara model pembelajaran kooperatif $C R H$ dengan model pembelajaran konvensional pada mata pelajaran ekonomi kelas XI MIPA di SMA Negeri 3 Purwokerto. Menganalisis perbedaan hasil belajar siswa antara model pembelajaran kooperatif $C R H$ dengan model pembelajaran konvensional pada mata pelajaran ekonomi kelas XI MIPA di SMA Negeri 3 Purwokerto. Menganalisis pengaruh model pembelajaran kooperatif $C R H$ terhadap keaktifan belajarpada mata pelajaran ekonomi kelas XI MIPA di SMA Negeri 3 Purwokerto. Menganalisis pengaruh model pembelajaran kooperatif $C R H$ terhadap hasil belajarpada mata pelajaran ekonomi kelas XI MIPA di SMA Negeri 3 Purwokerto. Menganalisis 
pengaruh keaktifan belajar siswa terhadap hasil belajar pada mata pelajaran ekonomi kelas XI MIPA di SMA Negeri 3 Purwokerto.

\section{Ruang Lingkup Penelitian}

Agar tidak terjadi perbedaan pemahaman, maka penelitian dibatasi pada masalahmasalah sebagai berikut: (1) Model pembelajaran yang digunakan dalam penelitian ini adalah model pembelajaran kooperatif tipe $C R H$ pada kelas eksperimen dan model pembelajaran konvensional pada kelas kontrol. (2) Hasil belajar yang diukur adalah hasil belajar dari aspek kognitif yang meliputi pengetahuan, pemahaman, aplikasi, dan analisis pada materi pelajaran yang dilakukan dengan pretest-posttest. (3) Keaktifan belajar yang akan diukur kepada siswa adalah pelakasanaan tugas, pemecahan masalah, keaktifan mengajukan pertanyaan, mencari berbagai informasi, diskusi kelompok, dan evaluasi diri.

\section{TINJAUAN PUSTAKA DAN PERUMUSAN HIPOTESIS}

\section{Hasil belajar}

Menurut Sudjana (2012:22) proses adalah "aktivitas pembelajaran yang dilakukan oleh siswa dalam mencapai tujuan pengajaran, sedangkan hasil belajar adalah kemampuankemampuan yang dimiliki siswa setelah ia menerima pengalaman belajar". Suprijono (2014:5-6) menjelaskan bahwa hasil belajar adalah pola-pola perbuatan, nilai-nilai, pengertian-pengertian, sikap-sikap, apresiasi, dan keterampilan yang diperoleh oleh siswa dalam proses pembelajaran.

Slameto (2010:54) menjelaskan bahwa terdapat dua faktor mempengaruhi keberhasilan seseorang dalam belajar, yaitu faktor intern (dari dalam diri siswa) meliputi faktor jasmaniah, faktor psikologis dan keaktifan siswa dalam bermasyarakat. Sedangkan faktor ektern (dari luar diri siswa) meliputi faktor keluarga, faktor sekolah, faktor masyarakat.

\section{Keaktifan belajar}

Menurut Sudjana (2010:61) keaktifan belajar adalah seberapa jauh tingkat aktifnya siswa saat ikut dalam proses pembelajaran dalam hal melaksankan tugas, memecahkan masalah atau persoalan, berusaha mencari informasi, melakukan diskusi, dan menerapkan apa yang diperolehnya ketika dalam proses pembelajaran. Menurut Aunurarahman (2013:119) "keaktifan anak dalam belajar merupakan persoalan penting yang mendasar yang harus dipahami, didasari dan dikembangkan oleh setiap guru di dalam setiap proses pembelajaran, dan juga berarti harus diterapakan oleh siswa dalam setiap bentuk aktifitas belajar".

Menurut Sudjana (2010:61) aktifnya siswa pada proses pembelajaran diperlihatkan dengan: "(1) Siswa akan turut serta untuk melaksanakan tugas belajarnya; (2) Siswa akan terlibat kedalam penyelesaian masalah; (3) Siswa akan berani mengajukan pertanyaan pada 
siswa lain atau guru apabila terdapat pemahaman yang kurang mengenai persoalan yang dihadapnya; (4) Siswa akan berusaha mencari sebanyak-banyaknya informasi yang relevan dan diperlukan untuk analisis sebuah masalah; (5) Siswa akan melakukan diskusi kelompok berdasarkan petunjuk guru; (6) Siswa akan dapat memberikan nilai untuk kemampuan dirinya dan hasil-hasil yang diperolehnya".

Menurut Aunurarahman (2013:121) "keaktifan siswa ini memberi banyak sekali manfaat baik manfaat yang langsung dirasakan pada saat terjadinya proses pembelajaran tersebut, maupun manfaat jangka panjang setelah proses pembelajaran itu terjadi. Teori-teori belajar pada hakikatnya adalah suatu perubahan. Perubahan-perubahan sebagai akibat hasil belajar sebagian mampu dilihat pada waktu relatif lama, bahkan bersamaan dengan belajar itu sendiri. Sebagian besar perubahan hasil belajar tersebut memerlukan waktu yang lama. Sedangkan perubahan tingkah laku mampu dilihat dengan waktu yang relatif singkat sebagai akibat terjadinya proses belajar misalnya perubahan-perubahan motorik atau aspek-aspek keterampilan".

\section{Model pembelajaran kooperatif}

Menurut Taniredja et al., (2011:55) pembelajaran kooperatif adalah pengajaran yang membuat siswa bekerjasama dalam pengerjaan tugas-tugas yang berstruktur. Pembelajaran kooperatif dikenal dengan pembelajaran secara berkelompok. Ciri-ciri pembelajaran kooperatif diantaranya terdapat kerja sama antar siswa, kelompok belajarnya memiliki kemampuan yang heterogen dan penekanan tidak hanya pada penyelesaian tugas tetapi juga hubungan interpersonal (hubungan antar pribadi yang saling menghargai)” (Triatno, 2009:110).

\section{Model pembelajaran kooperatif tipeCourse Review Horay (CRH)}

Huda (2013:236) mengemukakan bahwa model pembelaaran CRH yaitu model pembelajaran yang memiliki struktur yang menarik dan tidak membosankan karena disisipi hiburan yang menarik yang mengakibatkan suasana pembelajaran menjadi santai dan dapat mendorong siswa aktif untuk terjun ke dalamnya dan semangat belajar siswa akan meningkat karena aktivitas pembelajaran berlangsung menyenangkan. Menurut Shoimin (2014:54) model pembelajaran CRH merupakan salah satu pembelajaran kooperatif, yaitu "pembelajaran berkelompok dengan tujuan menguji pemahaman konsep siswa menggunakan kotak yang diisi dengan soal dan diberi nomor untuk menuliskan jawabannya. Siswa yang paling dahulu mendapatkan tanda benar langsung berteriak horay atau yel-yel lainnya".

Sintak atau langkah-langkah CRH yang dijelaskan Suprijono (2014:129) yaitu sebagai berikut : "(1) Guru menyampaikan kompetensi yang ingin dicapai oleh siswa; (2) Guru mendemonstrasikan/menyajikan materi; (3) Memberikan kesempatan siswa tanya jawab; (4) Untuk menguji pemahaman, guru membuat kotak 9/16/25 sesuai dengan kebutuhan dan tiap 
kotak diisi angka jawaban secara bebas; (5) Guru membaca soal secara acak dan siswa menulis jawaban di dalam kotak yang nomornya disebutkan guru dan langsung didiskusikan, kalau benar diisi dengan tanda $(\sqrt{ })$ dan salah diisi tanda silang (x); (6) Kelompok yang sudah mendapatkan tanda $(\sqrt{ })$ vertikal atau horizontal, atau diagonal harus berteriak hore...atau yel-yel lainnya; (7) Nilai kelompok dihitung dari jawaban benar jumlah hore yang diperoleh; (8) Penutup".

Kelebihan dan kekurangan model pembelajaran kooperatif tipe CRH yang dijelaskan oleh Shoimin (2014:54) adalah:

Kelebihan : (1) Menarik sehingga mendorong siswa terlibat aktif di dalamnya. (2) Tidak monoton karena diselingi sedikit hiburan sehingga suasana tidak menegangkan. (3) Siswa lebih semangat belajar. (4) Melatih kerja sama antar siswa.Kekurangan : (1) Adanya peluang untuk curang. (2) Siswa aktif dan pasif nilainya disamakan.

\section{Perumusan Hipotesis}

\section{Perbedaan keaktifan belajar siswa antara model pembelajaran kooperatif $C R H$ dengan model pembelajaran konvensional}

Menurut Dimyati dan Mudjiono (2009:51) guru akan menuntut siswa selalu aktif mencari, memperoleh, dan megelola perlorelahan belajarnya. Perilaku yang dilaksanakan guru yang dapat menimbulkan keaktifan belajar pada diri siswa diantaranya adalah penggunaan multimetode, model dan multimedia yang sesuai dengan topik yang akan diajarkan.

Menurut penelitian yang dilakukan oleh Supriani et al., (2017) menunjukan bahwa terdapat perbedaan yang signifikan keaktifan belajar IPA antara kelompok siswa yang di belajarkan model pembelajaran kooperatif tipe CRH dengan kelompok siswa yang dibelajarkan dengan model pembelajaran konvensional pada kelas IV di Desa Kalibukbuk Kecamatan Buleleng Tahun Pelajaran 2016/2017. Penelitian tersebut menunjukan bahwa keaktifan belajar pada kelas eksperimen lebih baik daripada kelas kontrol.Menurut penelitian Arti et al., (2016) menjelaskan bahwa terdapat perbedaan keaktifan belajar matematika siswa kelas VII SMP Kristen 2 Salatiga yang menggunakan model pembelajaran kooperatif tipe CRH dengan model pembelajaran konvensional dimana kelas eksperimen lebih baik daripada kelas kontrol atau kelas yang menggunakan model konvensional.

Mengacu pada uraian di atas, maka dapat dirumuskan hipotesis untuk penelitian ini adalah :

$\mathrm{H}_{1}$ : Terdapat perbedaan signifikan keaktifan belajar pada mata pelajaran ekonomi antara model pembelajaran kooperatif CRH dengan model pembelajaran konvensional. 


\section{Perbedaan hasil belajar siswa antara model pembelajaran kooperatif $C R H$ dengan model pembelajaran konvensional}

Menurut Slameto (2010:54) dijelaskan bahwa salah satu faktor memiliki pengaruh keberhasilan seseorang dalam belajar, yaitu keseseuaian penggunaan model pembelajaran, yang pada akhirnya akan terlihat di penilaian akhir hasil belajar. Penilaian adalah tolak ukur untuk mengetahui tercapai atau tidaknya tujuan pembelajaran.

Menurut penelitian yang dilakukan oleh Giri et al., (2013) terdapat perbedaan yang signifikan hasil belajar IPA antara siswa yang mengikuti pembelajaran dengan model $C R H$ dengan siswa yang mengikuti model pembelajaran konvensional di kelas IV di SD negeri Patas, Kecamatan Gerokgrak, Kabupaten Buleleng Tahun Pelajaran 2012/2013. Kelompok siswa yang mengikuti pembelajaran $C R H$ menunjukan hasil belajar IPA lebih tinggi dibandingkan dengan kelompok siswa yang mengikuti pembelajaran konvensional.Menurut penelitian yang dilakukan oleh Supriani et al., (2017) menunjukan bahwa terdapat perbedaan yang signifikan hasil belajar IPA antara kelompok siswa yang dibelajarkan model pembelajaran kooperatif tipe CRH dengan model pembelajaran konvensional pada kelas IV di Desa Kalibukbuk Kecamatan Buleleng Tahun Pelajaran 2016/2017. Pada penelitian tersebut dapat disimpulkan bahwa penggunaan model pembelajaran kooperatif tipe CRH lebih dapat meningkatan hasil belajar dibandingkan model konvensional.

Mengacu pada uraian di atas, maka dapat dirumuskan hipotesis untuk penelitian ini adalah :

$\mathrm{H}_{2}$ : Terdapat perbedaan signifikan hasil belajar pada mata pelajaran ekonomi antara model pembelajaran kooperatif CRH dengan model pembelajaran konvensional.

\section{Pengaruh model pembelajaran kooperatif CRH terhadap keaktifan belajar}

Model pembelajaran yang dapat digunakan dalam pembelajaran aktif dan bervariatif, salah satunya yaitu model pembelajaran kooperatif CRH. Menurut Huda (2013:236) kelebihan model pembelajaran kooperatif CRH strukturnya yang menarik dan dapat mendorong siswa aktif untuk dapat terjun ke dalamnya.

Menurut penelitian yang dilakukan oleh Arti et al., (2016) menunjukan bahwa model pembelajaran kooperatif tipe CRH memberikan pengaruh dan dampak positif pada keaktifan belajar dan hasil belajar matematika siswa kelas VII SMP Kristen 2 Salatiga. Astutika (2017) dalam penelitiannya menyimpulkan bahwa penggunaan model pembelajaran kooperatif tipe CRH dapat meningkatkan hasil belajar dan keaktifan siswa.

Mengacu pada uraian di atas, maka dapat dirumuskan hipotesis untuk penelitian ini adalah : 
$\mathrm{H}_{3}$ : Penggunaan model pembelajaran kooperatif $\mathrm{CRH}$ berpengaruh positif terhadap keaktifan belajar siswa mata pelajaran ekonomi.

\section{Pengaruh model pembelajaran kooperatif CRH pada hasil belajar}

Menurut Rusman (2010:209) dijelaskan bahwa model pembelajaran kooperatif sangat efektif dikembangkan untuk mencapai hasil belajar kompetensi akademik dan kompetensi sosial siswa. Ada beberapa variasi jenis model pembelajaran kooperatif, salah satunya adalah model pembelajaran CRH.

Menurut penelitian yang dilakukan oleh Rahmi et al., (2018) menunjukan bahwa model pembelajaran $\mathrm{CRH}$ berpengaruh positif pada hasil belajar ekonomi siswa. Artinya model pembelajaran yang berpusat pada siswa dapat melakukan peningkatan aktivitas belajar siswa dan berpengaruh positif pada hasil belajar siswa. Menurut penelitian yang dilakukan oleh Hermawan et al., (2013) menyimpulkan bahwa penggunaan metode pembelajaran CRH dapat men

ingkatkan hasil belajar siswa khususnya pada pelajaran Ilmu Gizi materi AKG pada siswa kelas X SMK N 3 Purworejo.

Mengacu pada uraian di atas, maka dapat dirumuskan hipotesis untuk penelitian ini adalah :

$\mathrm{H}_{4}$ : Penggunaan model pembelajaran kooperatif CRH berpengaruh positif terhadap hasil belajar siswa mata pelajaran ekonomi.

\section{Pengaruh keaktifan belajar siswa pada hasil belajar}

Menurut Aunurrahman (2013:119) pandangan mendasar yang perlu menjadi kerangka pikir setiap guru adalah bahwa pada prinsipnya anak-anak adalah makhluk yang aktif. Menurut Sudjana (2012:22) penilaian adalah upaya atau tindakan untuk mengetahui seberapa jauh keberhasilan dan proses hasil belajar siswa.

Menurut penelitian yang dilakukan oleh Dewi et al., (2016) menunjukan bahwa terdapat pengaruh yang positif dan signifikan konsep diri, keaktifan belajar dan minat baca literatur pada hasil belajar mata pelajaran akuntansi. Siagian, Fitria naulia (2017) dalam penelitiannya menjelaskan bahwa terdapat pengaruh yang signifikan antara keaktifan siswa dan fasilitas belajar pada hasil belajar siswa mata pelajaran IPS kelas VII SMP Negeri 3 Kota Jambi. Pada penelitian tersebut dapat disimpulkan bahwa pengaruh keaktifan siswa dan fasilitas belajar dapat meningkatkan hasil belajar.

Mengacu pada uraian di atas, maka dapat dirumuskan hipotesis untuk penelitian ini adalah : 
$\mathrm{H}_{5}$ : Keaktifan belajar siswa mata pelajaran ekonomi berpengaruh positif terhadap hasil belajar siswa mata pelajaran ekonomi.

\section{METODE PENELITIAN}

Jenis penelitian yang digunakan adalah penelitian kuantitatif dengan pendekatan eksperimen. Pada penelitian ini menggunakan metode eksperimen semu. Desain penelitian yang digunakan adalah Non Equivalent (pretest and posttest) control group design. Pada desain penelitian non equivalent control group design terdapat dua kelompok, yaitu kelompok kontrol dan kelompok eksperimen yang diberikan pretest dan posttest.

Populasi dalam penelitian ini adalah siswa kelas XI MIPA di SMA Negeri 3 Purwokerto yang terdiri dari 106 siswa yang terbagi menjadi 3 kelas yaitu kelas XI MIPA 1 sampai XI MIPA 3. Sedangkan sampel dalam penelitian ini adalah siswa kelas XI MIPA 2 dan XI MIPA 3 di SMA Negeri 3 Purwokerto yang berjumlah 61 siswa, karena didasarkan atas pertimbangan rata-rata kemampuan siswa yang hampir sama.

Langkah pertama penelitian ini adalah membandingkan kelas kontrol dan kelas eksperimen, dimana kelas eksperimen itu menggunakan model pembelajaran CRH dan kelas kontrol itu menggunakan model pembelajaran konvensional. Sehingga dapat mengetahui perbedaan keaktifan belajar dan hasil belajar antara kelas kontrol dan kelas eksperimen. Kerangka pemikiran dalam penelitian ini dapat dilihat pada gambar 1.

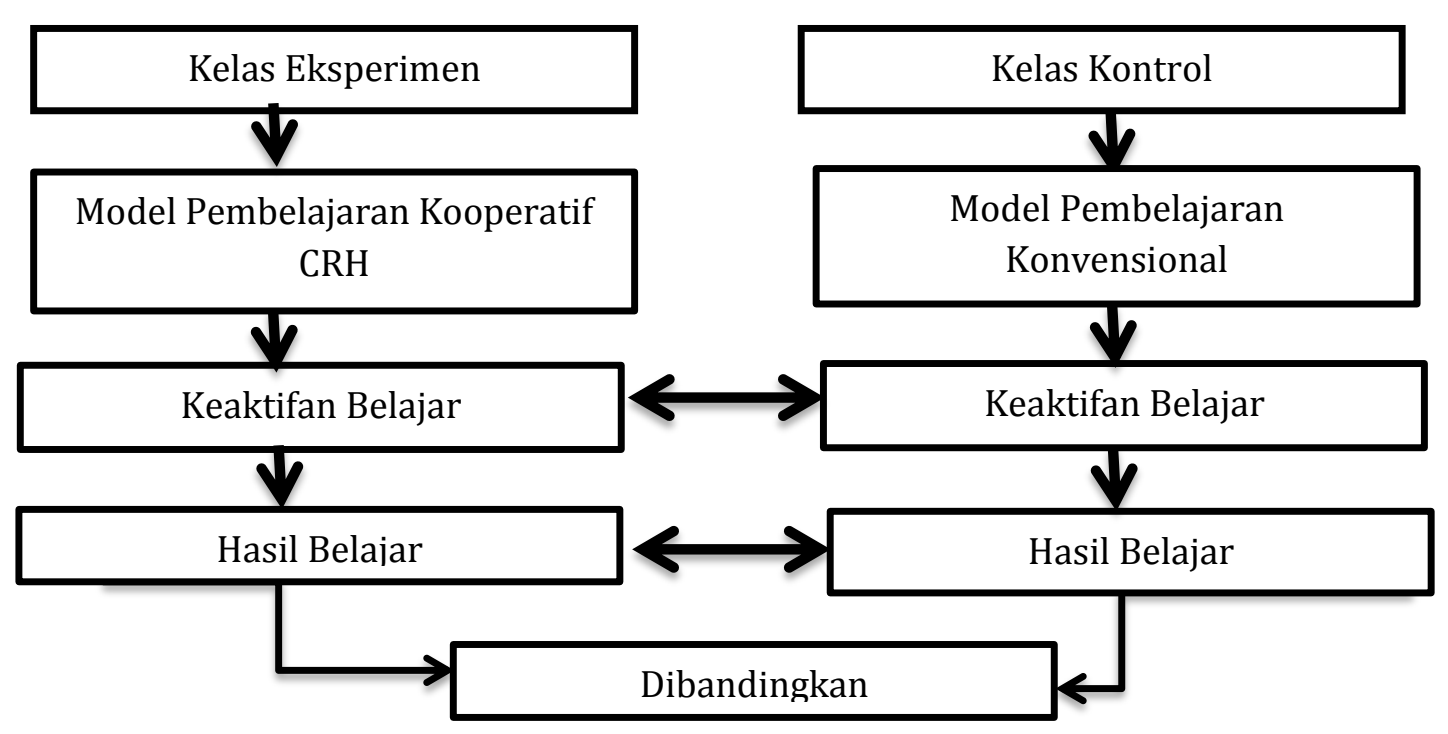

Gambar 1. Kerangka Berpikir 
Jenis data yang digunakan berupa data primer dan data sekunder. Dalam memperoleh data untuk penelitian ini penulis menggunakan teknik observasi, dokumentasi, teknik tes dengan pretest dan post test serta angket yang digunakan untuk mendapatkan informasi terkait keaktifan belajar siswa mata pelajaran ekonomi. Uji instrumen terdiri dari uji instrumen tes dan non tes. Instrumen diuji coba kepada kelas lain yang tidak digunakan penelitian untuk mengetahui validitas, reliabilitas, daya beda dan tingkat kesukaran soal. Sedangkan untuk uji instrumen non tes berupa angket terkait dengan keaktifan belajar siswa dengan menggunakan skala likert 1-4.

Sebelum dilakukan uji analisis data, maka data penelitian harus dilakukan uji asumsi klasik terlebih dahulu, dalam penelitian ini uji asumsi klasik meliputi uji normalitas dan uji homogenitas. Analisis data menggunakan uji t dan analisis regresi linier sederhana yang dilakukan menggunakan SPSS 23.

\section{HASIL DAN PEMBAHASAN}

Penelitian ini menganalisis mengenai pengaruh dan perbedaan penerapan model pembelajaran kooperatif tipe CRH terhadap keaktifan belajar dan hasil belajar ekonomi pada kelas XI MIPA di SMA Negeri 3 Purwoketo. Jumlah soal pretest, posttest, dan angket yang disiapkan masing-masing 72 buah, jumlah tersebut dibagi ke dalam dua kelas yaitu kelas XI IPA 2 sebagai kelas kontrol yang berjumlah 36 siswa dan kelas XI MIPA 3 sebagai kelas eksperimen yang berjumlah 36 siswa, akan tetapi pada pelaksanaan penelitian terdapat 2 siswa yang pindah sekolah, 1 siswa meninggal dunia, dan 8 siswa tidak hadir maka hanya ada 61 yang menjawab soal pretest, posttest, dan angket yang disebarkan.

Variabel keaktifan belajar terdiri dari enam indikator yang dijabarkan dalam 12 pertanyaan. Angka indeks variabel keaktifan belajar dilihat pada tabel 2 dan tabel 3.

Tabel 2. Jawaban Angket Responden Kelas Kontrol pada Variabel Keaktifan Belajar

\begin{tabular}{|c|c|c|c|c|c|c|}
\hline $\begin{array}{c}\text { Jawaban } \\
\text { (1) }\end{array}$ & $\begin{array}{c}\text { Skor } \\
(2)\end{array}$ & $\begin{array}{l}\text { Frekuensi } \\
\text { (3) }\end{array}$ & $\begin{array}{c}\text { Jumlah } \\
(2) \times(3)\end{array}$ & $\begin{array}{c}\text { Presentase } \\
(\%)\end{array}$ & $\begin{array}{c}\text { Rata- } \\
\text { rata }\end{array}$ & $\begin{array}{c}\text { Std } \\
\text { Deviation }\end{array}$ \\
\hline Sangat tidak setujı & 1 & 43 & 43 & $4,74 \%$ & \multirow{4}{*}{30,27} & \multirow{4}{*}{3,74} \\
\hline Tidak setuju & 2 & 152 & 304 & $33,48 \%$ & & \\
\hline Setuju & 3 & 99 & 297 & $32,71 \%$ & & \\
\hline Sangat setuju & 4 & 66 & 264 & $29,07 \%$ & & \\
\hline Jumlah & & 360 & 908 & $100 \%$ & & \\
\hline
\end{tabular}

Sumber : Data primer, diolah pada 2019

Mengacu pada tabel 2 dapat dilihat jawaban responden kelas kontrol 33,48\% memilih tidak setuju dan 4,74\% responden kelas kontrol memilih sangat tidak setuju, sedangkan ratarata keseluruhan keaktifan belajar siswa pada kelas kontrol adalah 30,27. Hal ini berarti keaktifan belajar yang dilakukan oleh siswa tergolong rendah pada mata pelajaran ekonomi karena sebagian besar menjawab tidak setuju. 
Tabel 3. Jawaban Angket Responden Kelas Eksperimen pada Variabel Keaktifan Belajar

\begin{tabular}{lcccccc}
\hline $\begin{array}{l}\text { Jawaban } \\
(1)\end{array}$ & $\begin{array}{c}\text { Skor } \\
(2)\end{array}$ & $\begin{array}{c}\text { Frekuensi } \\
(3)\end{array}$ & $\begin{array}{c}\text { Jumlah } \\
(2) \times(3)\end{array}$ & $\begin{array}{c}\text { Presentase } \\
(\%)\end{array}$ & $\begin{array}{c}\text { Rata- } \\
\text { rata }\end{array}$ & $\begin{array}{c}\text { Std } \\
\text { Deviation }\end{array}$ \\
\hline Sangat tidak & 1 & 8 & 8 & $0,75 \%$ & & \\
setuju & & & & & & \\
Tidak setuju & 2 & 103 & 206 & $19,29 \%$ & 34,45 & 3,91 \\
Setuju & 3 & 190 & 570 & $53,37 \%$ & & \\
Sangat setuju & 4 & 71 & 284 & $26,59 \%$ & & \\
\hline Jumlah & & 372 & 1068 & $100 \%$ & & \\
\hline
\end{tabular}

Sumber : Data primer, diolah pada 2019

Mengacu pada tabel 3 dapat dilihat jawaban responden kelas eksperimen 53,37\% memilih setuju, sedangkan rata-rata keseluruhan keaktifan belajar siswa pada kelas eksperimen adalah 34,45 . Hal ini berarti keaktifan belajar yang dilakukan oleh siswa tergolong cukup tinggi pada mata pelajaran ekonomi karena pada kelas eksperimen sudah menggunakan model pembelajaran kooperatif $C R H$.

Observasi merupakan suatu metode pengumpulan data melalui pengamatan. Metode ini digunakan untuk mendapatkan data yang berkaitan dengan keaktifan belajar siswa. Pada penelitian ini peneliti dibantu oleh seorang observer dalam mengamati keaktifan belajar siswa. Variabel keaktifan belajar siswa yang diamati oleh observer ada enam indikator. Berikut pada tabel 4 disajikan hasil observasi keaktifan siswa pada kelas kontrol.

Tabel 4. Hasil Observasi Keaktifan Belajar Siswa Kelas Kontrol

\begin{tabular}{llcc}
\hline No & \multicolumn{1}{c}{ Aspek yang diamati } & $\begin{array}{c}\text { Persentase } \\
(\%)\end{array}$ & $\begin{array}{c}\text { Rata-rata } \\
\text { Persentase(\%) }\end{array}$ \\
\hline 1 & Pelaksanaan Tugas & $43 \%$ & \\
2 & Pemecahan Masalah & $40 \%$ & $40 \%$ \\
3 & Mengajukan pertanyaan & $38 \%$ & \\
4 & Mencari Informasi & $35 \%$ & \\
5 & Diskusi & $40 \%$ & \\
6 & Evaluasi Diri & $44 \%$ & \\
\hline
\end{tabular}

Sumber : Data primer, diolah pada 2019

Bedasarkan tabel 4 dapat diketahui bahwa rata-rata keaktifan belajar pada kelas kontrol adalah 40\%, sehingga dapat disimpulkan bahwa keaktifan belajar pada kelas kontrol ada pada kategori rendah karena ada diantara 21\%-40\%.

Mengacu pada tabel 5 dapat diketahui bahwa rata-rata keaktifan belajar pada kelas eksperimen adalah 53\%. Hasil observasi keaktifan belajar menunjukan bahwa kelas yang menggunakan model pembelajaran kooperatif tipe CRH lebih optimal dibandingkan kelas 
dengan model konvensional, karena ada diantara 41\%-60\% sehingga berada pada kategori cukup tinggi.

Tabel 5. Hasil Observasi Keaktifan Belajar Siswa Kelas Eksperimen

\begin{tabular}{llcc}
\hline No & \multicolumn{1}{c}{ Aspek yang diamati } & $\begin{array}{c}\text { Persentase } \\
(\%)\end{array}$ & $\begin{array}{c}\text { Rata-rata } \\
\text { Persentase(\%) }\end{array}$ \\
\hline 1 & Pelaksanaan Tugas & $61 \%$ & \\
2 & Pemecahan Masalah & $50 \%$ & $53 \%$ \\
3 & Mengajukan pertanyaan & $60 \%$ & \\
4 & Mencari Informasi & $47 \%$ & \\
5 & Diskusi & $55 \%$ & \\
6 & Evaluasi Diri & $45 \%$ & \\
\hline
\end{tabular}

Sumber : Data primer, diolah pada 2019

Variabel hasil belajar dijabarkan dalam 15 pertanyaan mata pelajaran ekonomi kelas XI materi Perdagangan Internasional. Angka indeks hasil belajar pada kelas kontrol dan kelas eksperimen dilihat pada tabel 6.

Tabel 6. Data Hasil Belajar Kelas Kontrol dan Kelas Eksperimen

\begin{tabular}{lllccccc}
\hline \multirow{2}{*}{ No } & \multirow{2}{*}{ Deskripsi } & \multicolumn{3}{c}{ Kelas Kontrol } & \multicolumn{4}{c}{ Kelas Eksperimen } \\
& & Pretest & Posttest & Gain & Pretest & Posttest & Gain \\
\hline 1 & N & 30 & 30 & & 31 & 31 & \\
2 & Mean & 56 & 74 & 18 & 58 & 81 & 23 \\
3 & Std Deviation & 8,68 & 10,15 & 1,47 & 10,46 & 9,17 & 1,29 \\
4 & Minimum & 40 & 60 & 20 & 40 & 67 & 27 \\
5 & Maksimum & 73 & 93 & 20 & 80 & 100 & 20 \\
\hline
\end{tabular}

Sumber : Data primer, diolah pada 2019

Selanjutnya dilakukan uji normalitas, homogenitas. Berdasarkan hasil uji normalitas hasil belajar diperoleh chi square hitung soal pretest kelas eksperimen sebesar 14,581 dan kelas kontrol sebesar 10,800, chi square hitung soalpostest kelas eksperimen sebesar 9,667 dan kelas kontrol sebesar 11,000, Nilai tersebut lebih kecil dari chi square tabel maka dapat disimpulkan bahwa data hasil belajar adalah berdistribusi normal. Uji normalitas keaktifan belajar diperoleh chi square data kelas eksperimen yaitu 19,000 dan chi square data kelas kontrol yaitu 16,303. Pengujian homogenitas hasil pretest, postest dan angket antara kelas kontrol dan kelas eksperimen menunjukan bahwa nilai signifikansi lebih besar dari $\alpha(0,05)$ dapat dikatakan bahwa datanya homogen. Semua data tersebut memenuhi syarat untuk dilakukan uji selanjutnya.

Pengujian hipotesis menggunakan uji $\mathrm{t}$ dan analisis regresi sederhana. Uji $\mathrm{t}$ digunakan untuk mengetahui perbedaan keaktifan belajar dan hasil belajar siswa yang menggunakan model pembelajaran CRH dengan siswa yang menggunakan model pembelajaran konvensional pada mata pelajaran ekonomi kelas XI MIPA di SMA Negeri 3 Purwoerto. Berdasarkan hasil perhitungan diketahui nilai Sig dari t-Test sebesar 0,00 dan taraf signifikasinya adalah 0,05 . Nilai Sig $<$ 0,05 maka Ho ditolak dan Ha diterima. Sehingga kesimpulannya adalah terdapat perbedaan 
keaktifan belajar antara siswa yang menggunakan model pembelajaran CRH dengan siswa yang menggunakan model pembelajaran konvensional. Hasil penelitian ini mendukung hasil penelitian sebelumnya yang dilakukan Supriani et al., (2017) menunjukkan bahwa terdapat perbedaan yang signifikan keaktifan belajar IPA antara kelompok siswa yang di belajarkan model pembelajaran kooperatif tipe CRH dengan kelompok siswa yang dibelajarkan dengan model pembelajaran konvensional pada kelas IV di Desa Kalibukbuk Kecamatan Buleleng Tahun Pelajaran 2016/2017.

$\mathrm{H}_{1}$ : Terdapat perbedaan keaktifan belajar antara siswa yang menggunakan model pembelajaran kooperatif tipe CRH dengan siswa yang menggunakan model pembelajaran konvensional.

Hasil pengujian untuk perbedaan hasil belajar diketahui nilai Sig $(0,04)<0,05$ maka Ho ditolak dan Ha diterima. Sehingga kesimpulannya adalah terdapat perbedaan hasil belajar antara siswa yang menggunakan model pembelajaran CRH dengan siswa yang menggunakan model pembelajaran konvensional. Hasil penelitian ini mendukung hasil penelitian sebelumnya yang dilakukan oleh Menurut penelitian sebelumnya oleh Giri et al., (2013) menunjukkan bahwa terdapat perbedaan yang signifikan hasil belajar IPA antara siswa yang mengikuti pembelajaran dengan model CRH dengan siswa yang mengikuti model pembelajaran konvensional di kelas IV di SD negeri Patas, Kecamatan Gerokgrak, Kabupaten Buleleng Tahun Pelajaran 2012/2013. Kelompok siswa yang mengikuti pembelajaran CRH menunjukkan hasil belajar IPA lebih tinggi dibandingkan dengan kelompok siswa yang mengikuti pembelajaran konvensional.

$\mathrm{H}_{2}$ : Terdapat perbedaan hasil belajar antara siswa yang menggunakan model pembelajaran CRH dengan siswa yang menggunaka model pembelajaran konvensional.

Analisis uji regresi linier sederhana dilakukan untuk mengetahui pengaruh model pembelajaran $\mathrm{CRH}$ terhadap keaktifan belajar siswa. Berdasarkan perhitungan diketahui persamaan regresi linier sederhana untuk pengaruh model pembelajaran CRH terhadap keaktifan belajar siswa yaitu: $Y=30,267+4,188 X$

Hal tersebut menunjukkan bahwa konstanta sebesar 30,267 menggambarkan bahwa apabila variabel model pembelajaran tidak mengalami perubahan, maka keaktifan belajar sebesar 4,188satuan. Koefisien regresi model pembelajaran sebesar 4,188yang berarti model pembelajaran berpengaruh positif terhadap keaktifan belajar, atau dapat juga dikatakan bahwa jika model pembelajaran meningkat sebesar satu satuan, maka akan dapat meningkatkan keaktifan belajar sebesar 4,188satuan.

Perhitungan uji t dilakukan dengan menggunakan program SPSS. Hasil dari perhitungan tersebut diketahui bahwa nilai $t_{\text {hitung }}(4,266)$ lebih besar dibandingkan dengan nilai $t_{\text {tabel }}$ $(2,001)$. Hal ini menunjukkan bukti bahwa Ho ditolak dan Ha diterima yang berarti terdapat 
pengaruh positif penggunaan model pembelajaran kooperatif CRH terhadap keaktifan belajar siswa mata pelajaran ekonomi di SMA Negei 3 Purwokerto.

$\mathrm{H}_{3}$ : Model pembelajaran CRH berpengaruh positif terhadap keaktifan belajar

Analisis uji regresi linier sederhana dilakukan untuk mengetahui pengaruh model pembelajaran CRH terhadap hasil belajar siswa. Berdasarkan perhitungan diketahui persamaan regresi linier sederhana untuk pengaruh model pembelajaran CRH terhadap keaktifan belajar siswa yaitu: $Y=73,566+7,509 \mathrm{X}$

Dari persamaan tersebut penjelasannya adalah sebagai berikut: Konstanta sebesar 73,566 menunjukkan bahwa apabila variabel model pembelajaran konstan, maka hasil belajar sebesar 7,509satuan. Koefisien regresi model pembelajaran sebesar 7,509yang berarti model pembelajaran berpengaruh positif terhadap hasil belajar, atau dapat juga dikatakan bahwa jika model pembelajaran meningkat sebesar satu satuan, maka akan meningkatkan hasil belajar sebesar 7,509satuan.

Perhitungan uji t dilakukan dengan menggunakan program SPSS. Hasil dari perhitungan tersebut diketahui bahwa nilai $t_{\text {hitung }}(3,021)$ lebih besar dibandingkan dengan nilai $t_{\text {tabel }}$ $(2,001)$. Hal ini menunjukkan bukti bahwa Ho ditolak dan Ha diterima yang berarti terdapat pengaruh positif penggunaan model pembelajaran kooperatif CRH terhadap hasil belajar siswa mata pelajaran ekonomi di SMA Negei 3 Purwokerto.

$\mathrm{H}_{4}$ : Model pembelajaran CRH berpengaruh positif terhadap hasil belajar

Analisis uji regresi linier sederhana dilakukan untuk mengetahui pengaruh keaktifan belajar terhadap hasil belajar siswa. Berdasarkan perhitungan diketahui persamaan regresi linier sederhana untuk pengaruh keaktifan belajar terhadap hasil belajar yaitu: $Y=60,467+$ $0,522 \mathrm{X}$

Dari persamaan tersebut penjelasannya yaitu: konstanta sebesar 60,467 menunjukkan bahwa apabila variabel keaktifan belajar tidak mengalami perubahan, maka keaktifan belajar sebesar 0,522satuan. Koefisien regresi keaktifan belajar sebesar 0,522yang berarti keaktifan belajar berpengaruh positif terhadap hasil belajar, atau dapat dikatakan jika keaktifan belajar meningkat sebesar satu satuan, maka akan meningkatkan hasil belajar sebesar 0,522satuan.

Perhitungan uji t dilakukan dengan menggunakan program SPSS. Hasil dari perhitungan tersebut diketahui bahwa nilai $t_{\text {hitung }}(1,727)$ lebih kecil dibandingkan dengan nilai $t_{\text {tabel }}$ $(2,001)$. Hal ini menunjukkan bukti bahwa Ho diterima dan Ha ditolak yang berarti tidak terdapat pengaruh positif keaktifan belajar terhadap hasil belajar siswa mata pelajaran ekonomi di SMA Negeri 3 Purwokerto.

$\mathrm{H}_{5}$ : Keaktifan belajar tidak berpengaruh positif terhadap hasil belajar 


\section{KESIMPULAN}

Terdapat perbedaan signifikan keaktifan belajar antara model pembelajaran kooperatif $C R H$ dengan model pembelajaran konvensional pada mata pelajaran ekonomi kelas XI MIPA di SMA Negeri 3 Purwokerto. Hal ini menunjukkan bahwa keaktifan belajar dengan menggunakan model pembelajaran kooperatif $C R H$ lebih baik dibandikan menggunakan model konvensional. Terdapat perbedaan signifikan hasil belajar antara model pembelajaran kooperatif $C R H$ dengan model pembelajaran konvensional pada mata pelajaran ekonomi kelas XI MIPA di SMA Negeri 3 Purwokerto. Hal ini menunjukkan bahwa hasil belajar dengan menggunakan model pembelajaran kooperatif $C R H$ lebih baik dibandikan menggunakan model konvensional. Terdapat pengaruh positif model pembelajaran kooperatifCRH terhadap keaktifan belajar pada mata pelajaran ekonomi kelas XI MIPA di SMA Negeri 3 Purwokerto. Pada saat model pembelajarankooperatifCRH meningkat maka keaktifan belajar siswa juga meningkat, begitu pun sebaliknya ketika model pembelajarankooperatifCRH menurun maka keaktifan belajar siswa juga menurun. Hal ini menunjukkan bahwa model pembelajarankooperatif $C R H$ berpengaruh positif dalam meningkatkan keaktifan belajar siswa pada mata pelajaran ekonomi. Terdapat pengaruh positif model pembelajaran kooperatif $C R H$ terhadap hasil belajar pada mata pelajaran ekonomi kelas XI MIPA di SMA Negeri 3 Purwokerto. Pada saat model pembelajarankooperatif $C R H$ meningkat maka hasil belajar siswa juga meningkat, begitu pun sebaliknya ketika model pembelajarankooperatifCRH menurun maka hasil belajar siswa juga menurun. Hal ini menunjukkan bahwa model pembelajarankooperatif $C R H$ berpengaruh positif dalam meningkatkan hasil belajar siswa pada mata pelajaran ekonomi. Tidak terdapat pengaruh positif antara keaktifan belajar siswa terhadap hasil belajar pada mata pelajaran ekonomi kelas XI MIPA di SMA Negeri 3 Purwokerto. Pada saat keaktifan belajar berubah maka akan mengubah hasil belajar. Hal ini menunjukkan bahwa keaktifan belajar tidak berpengaruh positif terhadap hasil belajar pada mata pelajaran ekonomi.

\section{DAFTAR PUSTAKA}

Arti, Bernike Krisbudi, Kriswandani, dan Tri Nova Hasti Yunianta. 2016. Pengaruh Model Pembelajaran Kooperatif Tipe Course Review Horay Terhadap Keaktifan belajar dan Hasil Belajar Matematika Pada Materi Aritmatika Sosial Bagi Siswa Kelas VII SMP Kristen 2 Salatiga Semester 2 Tahun ajaran 2015/2016. Jurnal Pendidikan Matematika.Fakultas Keguruan dan Ilmu Pendidikan, Universitas Kristen Satya Wacana.

Aunurrahman. 2013. Belajar dan Pembelajaran. Bandug: Alfabeta. 
Dewi, Elisabet Sukma, Komeng Winartha, dan Tedi Rusman. 2016. Pengaruh Konsep Diri, Keaktifan dan Minat Baca Literatur Terhadap Hasil Belajar Akuntansi. Jurnal Edukasi Ekobis. FKIP, UNILA. Vol 4 No 3.

Dimyati, dan Mudjiono. 2009. Belajar dan Pembelajaran. Jakarta: Rineka Cipta.

Giri, Komang Rosita, Nyoman Wirya, dan Dewa Putu Raka Rasana. 2013. Pengaruh Model Pembelajaran Course Review Horay Terhadap Hasil Belajar IPA Siswa Kelas IV. Jurnal PGSD dan PGPAUD. Universitas Pendidikan Ganesha Singaraja, Indonesia.

Hermawan, Puput, Siti Kamsiyati, dan Idan Ragil Widianto Atmojo. 2013. Pengaruh Model Kooperatif Tipe Course Review Horay (CRH) Terhadap Hasil Belajar IPA. Jurnal PGSD. FKIP, Universitas Sebelas Maret.

Huda, Miftahul. 2013. Model-model Pengajaran dan Pembelajaran. Yogyakarta: Pustaka Pelajar.

Rahman, Muhammat, dan Sofan Amri. 2014. Model Pembelajaran Arias Terintegratif. Jakarta: PT Prestasi Pustakaraya

Rahmi, Cynthia, Sri Kartikowati, dan Gani Haryana. 2018. Pengaruh Model Kooperatif Tipe Course Review Horay Terhadap Hasil Belajar Ekonomi Siswa Kelas XI IIS SMA Nurul Falah Pekanbaru. Jurnal Pendidikan Ekonomi. Fakultas Keguruan dan Ilmu Pendidikan, Universitas Riau.Vol 5(hal 1-7).

Rusman. 2013. Model-Model Pembelajaran. Jakarta: PT Raja Grafindo Perseda.

Shoimin, Aris. 2014. 68 Model Pembelajaran Inovatif dalam Kurikulum 2013. Yogyakarta: Ar-Ruzz Media.

Siagian, Fitri Nauli. 2017. Pengaruh Keaktifan Siswa Dan Fasilitas Belajar Terhadap Hasil Belajar Siswa Pada Mata Pelajaran Ips Kelas VII SMP Negeri 3 Kota Jambi . Jurnal Pendidikan Ekonomi. Fakultas Keguruan dan Ilmu Pendidikan, Universitas Jambi.

Slameto. 2010. Belajar dan Faktor-Faktor yang Mempengaruhinya. Jakarta: PT Rineka Cipta.

Sudjana, Nana. 2010. Penilaian Hasil Proses Belajar Mengajar. Bandung: PT Remaja Rosdakarya Offset. . 2012. Penilaian Hasil Proses Belajar Mengajar. Bandung: PT Remaja Rosdakarya Offset

Suprijono, Agus. 2013. Cooperative Learning. Surabaya: Pustaka Belajar. . 2014. Cooperative Learning Teori dan Aplikasi PAIKEM. Yogyakarta: Pustaka Pelajar.

Supriyani, Rita Ketut, Kadek Suartama, dan Dewi Arum Widhiyanti Metra Putri. 2017. Pengaruh Model Pembelajaran Kooperatif Course Review Horay Terhadap Keaktifan dan Hasil Belajar IPA. E-Journal PGSD Universitas Pendidikan Ganesha. Vol 5 No 2.

Suyatno. 2009. Menjelajah Pembelajaran Inovatif. Surabaya: Masmedia Buana Pustaka. 
Taniredja, Tukiran, Efi Miftah Faridli, dan Sri Harmianto. 2011. Model-model Pembelajaran Inovatif. Bandung: Alfabeta.

Triatno. 2009. Mendesain Model Pembelajaran Inovatif-Progresif. Jakarta: Kencana Prenada Media Group.

Triatno, Ibnu Badar dan AL-Tabany. 2014. Mendesain Model Pembelajaran Inovatif, Progresif, dan Kontekstual: Konsep, Landasan dan Implementasinya pada Kurikulum 2013. Jakarta: Prenamedia. 